\title{
Fracture strength of implant abutments after fatigue testing: A systematic review and a meta-analysis
}

\author{
Coray, Rafaela ; Zeltner, Marco ; Özcan, Mutlu
}

\begin{abstract}
PURPOSE The use of implants and their respective suprastructures to replace missing teeth has become a common therapeutic option in dentistry. Prior to their clinical application, all implant components have to demonstrate suitable durability in laboratory studies. Fatigue tests utilising cyclic loading typically simulate masticatory function in vitro. The objectives of this systematic review were to assess the loading conditions used for fatigue testing of implant abutments and to compare the fracture strength of different types of implant abutment and abutment-connection types after cyclic loading. MATERIALS AND METHODS Original scientific papers published in MEDLINE (PubMed) and Embase database in English between 01/01/1970 and 12/31/2014 on cyclic loading on implant abutments were included in this systematic review. The following MeSH terms, search terms and their combinations were used: "in vitro" or "ex vivo" or experimental or laboratory, "dental implants", "implants, experimental", "dental prosthesis, implant-supported", "fatigue", "dental abutments", "cyclic loading", "cyclic fatigue", "mechanical fatigue", "fatigue resistance", "bending moments", and "fracture". Two reviewers performed screening and data abstraction. Only the studies that reported, static fracture values before and after fatigue cycling of implant abutments, were included that allowed comparison of aging effect through cyclic loading. Data $(\mathrm{N})$ were analyzed using a weighted linear regression analysis $(\alpha=0.05)$. RESULTS The selection process resulted in the final sample of 7 studies. In general, loading conditions of the fatigue tests revealed heterogeneity in the sample but a meta-analysis could be performed for the following parameters: a) abutment material, b) implant-abutment connection, and (c) number of fatigue cycles. Mean fracture strength of titanium $(508.9 \pm 334.6 \mathrm{~N})$ and for zirconia abutments $(698.6 \pm 452.6 \mathrm{~N})$ did not show significant difference after cyclic loading $(\mathrm{p}>0.05)$. Internal implant-abutment connections demonstrated significantly higher fracture strength after cyclic loading compared to external ones (internal: $774.0 \pm 582.3 \mathrm{~N}$; external: $481.2 \pm 137.5 \mathrm{~N} ; \mathrm{p}=0.022$ ). The mean fracture strength of all abutment types decreased significantly when number of loading cycles exceeded $1,000,000$ cycles $(<1 \times 10(-6): 1047.0 \pm 751.3 \mathrm{~N} ;>1 \times 10(-6): 556.7 \pm 317.6 \mathrm{~N} ; \mathrm{p}=0.032)$. CONCLUSION The results of this meta-analysis, favour the use of internal implant-abutment connections in combination with either titanium or zirconia abutment materials. Number of cycles had a significant impact on the fracture strength after cyclic loading.
\end{abstract}

DOI: https://doi.org/10.1016/j.jmbbm.2016.05.011

Posted at the Zurich Open Repository and Archive, University of Zurich ZORA URL: https://doi.org/10.5167/uzh-127853

Journal Article

Accepted Version

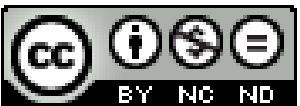


The following work is licensed under a Creative Commons: Attribution-NonCommercial-NoDerivatives 4.0 International (CC BY-NC-ND 4.0) License.

Originally published at:

Coray, Rafaela; Zeltner, Marco; Özcan, Mutlu (2016). Fracture strength of implant abutments after fatigue testing: A systematic review and a meta-analysis. Journal of the Mechanical Behavior of Biomedical Materials, 62:333-346. DOI: https://doi.org/10.1016/j.jmbbm.2016.05.011 
Fracture strength of implant abutments after fatigue testing: A systematic review and a metaanalysis

Rafaela Coray ${ }^{\mathrm{a}}$, Marco Zeltner ${ }^{\mathrm{a}}$, Mutlu Özcan ${ }^{\mathrm{a},{ }^{*}}$

aUniversity of Zürich, Dental Materials Unit, Center for Dental and Oral Medicine, Clinic for Fixed and Removable Prosthodontics and Dental Materials Science, Plattenstrasse 11, CH-8032, Zurich, Switzerland

Short title: Implant abutment strength after fatigue testing

*Corresponding author at: Mutlu Özcan, Prof. Dr.med.dent., Ph.D., Dental Materials Unit, University of Zurich, Center for Dental and Oral Medicine, Clinic for Fixed and Removable Prosthodontics and Dental Materials Science, Plattenstrasse 11, CH 8032, Zurich, Switzerland. Tel: +41 44 6343251; fax: +41 44 6344305. E-mail address: mutluozcan@hotmail.com 


\section{ABSTRACT}

Purpose: The use of implants and their respective suprastructures to replace missing teeth has become a common therapeutic option in dentistry. Prior to their clinical application, all implant components have to demonstrate suitable durability in laboratory studies. Fatigue tests utilizing cyclic loading typically simulate masticatory function in vitro. The objectives of this systematic review were to assess the loading conditions used for fatigue testing of implant abutments and to compare the fracture strength of different types of implant abutment and abutment-conncetion types after cyclic loading.

Materials and Methods: Original scientific papers published in MEDLINE (PubMed) and Embase database in English between 01/01/1970 and 12/31/2014 on cyclic loading on implant abutments were included in this systematic review. The following MeSH terms, search terms and their combinations were used: "in vitro" or "ex vivo" or experimental or laboratory, "dental implants", "implants, experimental", "dental prosthesis, implant-supported", "fatigue", "dental abutments", "cyclic loading", "cyclic fatigue", "mechanical fatigue", "fatigue resistance", "bending moments", and "fracture". Two reviewers performed screening and data abstraction. Only the studies that reported, static fracture values before and after fatigue cycling of implant abutments, were included that allowed comparison of aging effect through cyclic loading. Data $(N)$ were analyzed using a weighted linear regression analysis $(\alpha=0.05)$.

Results: The selection process resulted in the final sample of 7 studies. In general, loading conditions of the fatigue tests revealed heterogeneity in the sample but a meta-analysis could be performed for the following parameters: a) abutment material, b) implant-abutment connection, and c) number of fatigue cycles. Mean fracture strength of titanium $(508.9 \pm 334.6 \mathrm{~N})$ and for zirconia abutments $(698.6 \pm 452.6 \mathrm{~N})$ did not show significant difference after cyclic loading $(p>0.05)$. Internal implant-abutment connections demonstrated significantly higher fracture strength after cyclic loading compared to external ones (internal: $774.0 \pm 582.3 \mathrm{~N}$; external: $481.2 \pm 137.5 \mathrm{~N} ; \mathrm{p}=0.022)$. The mean fracture strength of all abutment types decreased significantly when number of loading cycles exceeded 1'000'000 cycles $\left(<1 \times 10^{-6}: 1047.0 \pm 751.3\right.$ $\left.\mathrm{N} ;>1 \times 10^{-6}: 556.7 \pm 317.6 \mathrm{~N} ; \mathrm{p}=0.032\right)$. 
Conclusion: The results of this meta-analysis, favour the use of internal implant-abutment connections in combination with either titanium or zirconia abutment materials. Number of cycles had a significant impact on the fracture strength after cyclic loading.

Keywords: Fatigue; Cyclic loading; Dental abutments; Dynamic loading; Fatigue resistance; Mechanical test 


\section{Introduction}

The use of implants and their respective suprastructures to replace single or multiple missing teeth has become a common practice in dentistry. Although implant dentistry is already highly evolved, frequently new materials and designs are being continuously introduced. Today, vast numbers of implant systems with different components are available. While osseointegration is well established, the complications with implant-borne fixed dental prosthesis (FDP) and implant components are not completely eliminated (Strub and Gerds, 2003). In this context, not only the implant itself but also the durability of the type of abutment, the implant-abutment connection, and the abutment material have to be considered. With the advances in the computer-aided design/computer-aided manufacturing (CAD/CAM) technologies, high-strength ceramic materials are also incorporated as abutment materials as an alternative to traditionally used metal abutments in implant dentistry.

Since worldwide implant therapies are still considered costly treatment options, various prerequisites in terms of biocompatibility and mechanical durability needs to be met prior to their clinical application (Strub and Gerds, 2003). Among the mechanical properties, fracture strength or in other terms load-bearing capacity is considered to be one of the most important features for implant components. Static fracture tests are commonly applied to determine the strength of the abutments but in fact, they do not simulate the masticatory function, since certain factors such as time and the environment are excluded in such tests. Ideally, an in vitro test should simulate the clinical situation as close as possible so that translational meaning of the in vitro tests would be high (Alqahtani and Flinton, 2014). These requirements are best met by fatigue testing where implant components are exposed to cyclic loading (Dittmer et al., 2012). However, dental literature do not present controlled and standardized environment for cyclic loading conditions in implant dentistry. Although implant components are expected to fulfil ISO 14801 (ISO 14801., 2007) before they are launched in the dental market, an increasing number of studies are being published with diverse parameters used for cyclic loading, making comparison of durability of implant types and abutments nearly impossible. 
The objectives of this systematic review therefore were to assess the loading conditions used for fatigue testing of implant abutments and to compare the fracture strength of different types of implant abutments before and after cyclic loading.

\section{Material and methods}

\subsection{Search strategy}

An electronic search at MEDLINE (PubMed) (http://www.ncbi.nlm.nih.gov/pubmed/) and Embase from 01/01/1970 to 31/07/2014 wad conducted for articles in English only. Following MeSH terms, search terms and their combinations were used for this search: "in vitro" or "ex vivo" or experimental or laboratory, "dental implants", "implants, experimental", "dental prosthesis, implant-supported", "fatigue", "dental abutments", "cyclic loading", "cyclic fatigue", "mechanical fatigue", "fatigue resistance", "bending moments", and "fracture" (Table 1). The MEDLINE search yielded 345 references to be screened for possible inclusion based on titles and abstracts (Fig. 1). A further manual search covering the period from 01/01/1990 up to and including 31/07/2014 was performed on the following journals: Clinical Implant Oral Research, Clinical Implant Related Research, Implant Dentistry, Journal of Dental Research, Dental Materials, International Journal of Prosthodontics, Journal of Prosthetic Dentistry, Journal of Prosthodontics, European Journal of Prosthetic and Restorative Dentistry, International Journal of Oral Maxillofacial Implants. In addition, hand searches were performed on bibliographies of the selected articles as well as identified narrative reviews to find out whether the search process has missed any relevant article. This added to one additional article to be involved in the review process.

\subsection{Inclusion/Exclusion criteria}

English language articles reporting on in vitro studies testing implant abutments and implant-abutment connection types, specifications of the investigated abutment materials, cyclic loading protocols, fracture 
strength or bending moments after the mechanical testing were included. Studies evaluating implant abutments in combination with an additional suprastructure such as a crown were excluded.

\subsection{Selection of studies}

Two independent reviewers (M.Z. and M.Ö.) performed the search process where 345 articles were found to have potential for possible inclusion in this systematic review. After screening the titles derived from the initial search based on the inclusion criteria, abstracts were screened and reviewed by both reviewers for meeting the inclusion criteria. Based on the selected abstracts, articles were subsequently obtained in full text. Thereafter, 60 articles were selected after reading their abstracts. The full texts of the chosen articles were then obtained and evaluated for inclusion in this review, leading to 33 relevant articles. Disagreements during the screening process were solved by discussion aiming for consensus.

\subsection{Data extraction}

The data collection form containing 21 items was created and used to evaluate the experimental environment of the in vitro studies described in the 33 relevant articles concerning cyclic fatigue tests. The variables were recorded and tabulated in Excel sheets. Variables of studies, which could not be extractec or calculated, were scored as 'not reported, nr'.

\subsection{Statistical analysis}

Statistical analyses were performed using the Statistical Package for the Social Sciences (version 22.0, SPSS Inc, Chicago, IL, USA). The inter-observer agreement with respect to the reporting of experimental conditions of the included abstracts before the consensus meeting is expressed as weighted Cohen's kappa. For descriptive statistics means and standard deviations, or medians and interquartile ranges in skewed distributions were noted. A weighted linear regression was applied for the meta-analysis of the following parameters: abutment material, implant-abutment connection type, number of loading cycles and fracture strength. 


\section{Results}

\subsection{Study selection}

The publications qualified for inclusion are presented in Table 2. The Kappa score for agreement between the reviewers for screening of abstracts was 0.85. In the selected 7 articles (Boggan et al., 1999; Huang ef al., 2005; Gehrke et al., 2006; Dittmer et al., 2012; Truninger et al., 2012; Stymmelmayr et al., 2013 Alqahtani and Flinton, 2014), a total of 165 experimental subgroups were identified where fracture strength results were reported in N. Finally, 7 articles met the inclusion criteria. All studies were in vitro studies published between 1999 and 2014. Excluded articles are listed in Table 4.

\subsection{Testing parameters}

Loading conditions in the selected sample revealed a large heterogeneity. In all of the included studies, forces were applied on the abutments in a different testing machine with either a stainless steel or a cobalt chromium indenter (Table 1). The loading forces varied between $10 \mathrm{~N}$ and $1995 \mathrm{~N}$ with a frequency of 2-15 Hz. While the specimens were loaded at 30 degrees in 6 studies (Boggan et al., 1999; Huang et al., 2005; Gehrke et al., 2006; Dittmer et al., 2012; Truninger et al., 2012; Stimmelmayr et al., 2013 Alqahtani and Flinton 2014), in one study the loading force was applied 45 degrees of axis (Alqahtani and Flinton, 2014). In three studies the temperature of the environment ranged between $5-55^{\circ} \mathrm{C}$ (Boggan et al., 1999; Truninger et al., 2012; Stimmelmayr et al., 2013). The cyclic loading environment was specified in 4 studies as $0.9 \%$ saline (Boggan et al., 1999), saliva substitute (Alqahtani and Flinton, 2014), lubricant film (Dittmer et al., 2012) or water (Truninger et al., 2012). The number of cyclic loading varied between $25^{\prime} 000$ and 5'000'000. In three studies the number of cycles was below 1'000'000 (Boggan et al., 1999; Stimmelmayr et al., 2013; Alqahtani and Flinton, 2014;) and in four studies it was equal to or more than 1'000'000 (Huang et al., 2005; Gehrke et al., 2006; Dittmer et al., 2012; Truninger et al., 2012). The specimens were loaded at a crosshead speed ranging between 0.5 and $3 \mathrm{~mm} / \mathrm{min}$. 


\subsection{Fracture strength results}

Fracture strength of the abutments before cyclic loading was assessed in three studies (Huang et al., 2005; Boggan et al., 1999; Dittmer et al., 2012) (Table 3a). All of these abutments were made out of titanium and fracture strength ranged between $430 \pm 59 \mathrm{~N}$ and $1955 \pm 18 \mathrm{~N}$.

Fracture strength of titanium $(508.9 \pm 334.6 \mathrm{~N})$ and for zirconia abutments $(698.6 \pm 452.6 \mathrm{~N})$ did not show significant difference after cyclic loading $(p>0.05)$.

Internal implant-abutment connections demonstrated significantly higher fracture strength after cyclic loading compared to external implant-abutment connections (internal: $774.0 \pm 582.3 \mathrm{~N}$; external: $481.2 \pm 137.5 \mathrm{~N} ; \mathrm{p}=0.022)($ Table $3 b)$.

The mean fracture strength of all abutment types decreased significantly when number of loading cycles exceeded 1'000'000 cycles $\left(<1 \times 10^{-6}: 1047.0 \pm 751.3 \mathrm{~N} ;>1 \times 10^{-6}: 556.7 \pm 317.6 \mathrm{~N} ; \mathrm{p}=0.032\right)$.

\section{Discussion}

The use of implants as a substitute for lost teeth has become a common solution in dentistry. In order to decrease the failure rates of implants, the results of preclinical studies are considered in comparing performance and ranking of implant components. Especially the results of tests representing the worsecase scenarios help clinicians decide for implant systems that stay stable in long term clinical service. This systematic review was performed in an attempt to assess the loading conditions used for fatigue testing of implant abutments and to compare the fracture strength of implant abutments made of titanium or zirconia before and after cyclic loading. Based on the results of this study, not the abutment material but the implant-abutment connection type affected the results.

Cyclic fatigue loading test intend to investigate the mechanical durability of dental reconstruction materials prior to clinical trials in order to avoid costly interventions upon failures. Yet, to date the parameters employed by the investigators such as the number of fatigue cycles, loading jigs, frequency of loading, presence of humid environment, involvement of hydrothermal aging conditions show a great variation in the current dental literature. Although static fracture tests may help to screen the durability of 
implant components, one of the main causes of structural failure in implant dentistry is often as a consequence of fatigue. In that respect, cyclic loading could be considered a more clinically relevant testing approach. It has been reported that dental restorations fail more frequently under cyclic loading tests that are well below the ultimate flexural strength of these materials as opposed to the application of a single, relatively higher static load (Kelly et al., 2012). Thus, repeated stresses can predispose restorations to fail under fatigue. No universal standard is presently available for such test methodologies for reconstructive dentistry. In fact for implant dentistry, ISO 14801 serves as the only standard which requires $1 \times 10^{-6}$ cycles with an upper load limit of $100 \mathrm{~N}$ at $30^{\circ}$ axial loading. It has been previously reported that $2 \times 10^{6}$ cycles correspond to approximately four years of normal occlusal and masticatory activity (Baldissara et al., 2010). In this sample, 5 of the selected studies practiced cyclic loading for 1 or more than $1 \times 10^{-6}$ but 2 studies performed cycling less than $1 \times 10^{-6}$. Nevertheless, in all studies fatigue loading tends to decrease the results regardless of the cyclic conditions. In addition, ISO 14801 requires embedding the implants with $2 \mathrm{~mm}$ implant neck exposure prior to loading in order to increase the torque effect. In this sample, only 2 studies loaded the specimens after such a modification. One study analyzed the influence of modifications on the fracture strength of internally connected zirconia abutments comparing unmodified abutments with modified ones and concluded that modifications after the sintering zirconia negatively affected the fracture strength results (Alqahtani and Flinton, 2014).

One major problem during the search process was the heterogeneity of $\mathrm{MeSH}$ and search terms related to cyclic loading or other fatigue related terms. In the dental literature, a great number of different terms are being used in order to describe some mechanical aging procedures for implant materials. This issue needs to be solved primarily so that future studies could report on identical search terms. Furthermore, in order to investigate the aging effect of cyclic loading on the durability on implant materials, the materials should be tested with and without exposure to cyclic loading. Unfortunately, the majority of the reason for exclusion was that the reconstructions were tested together with the abutments or that static loading was not performed after cyclic loading at all that did not give the possibility to compare the aging effect of cyclic loading. Crowns are tested on the abutments after some cyclic loading could not single out the real effect 
of aging procedures on the abutment since the principle forces are exposed on the reconstruction material and not on the abutment. There were altogether 7 studies selected through which the research questions could be answered to some extend. Such studies are usually costly and the number of these studies on abutments only, was less than those of the studies on crown-abutment combinations $(n=18)$. Moreover, the number of specimens per group varied between 3 and 35 . The statistical analysis required at least 6 specimens with identical test parameters to make more predictable assumptions.

The loading magnitude varied from 10 to $1995 \mathrm{~N}$ with stainless steel or cobalt chromium indenters with rounded tips. The diameters of the indenters were not enclosed in all studied. In fact, cone crack or Herzian crack formation especially on zirconia is highly dependent on the diameter and sharpness of the indenter (Lawn et al., 2001). Similarly, the temperature of the environment during cycling loading were either not reported or ranged between 5 and $55^{\circ} \mathrm{C}$. Thus, temperature and medium related corrosion process could not be considered similar between the selected studies. Therefore, current studies regarding the fatigue strength of dental implant components should be evaluated cautiously considering the testing conditions. Some more systematic approach especially regarding the testing and reporting fatigue and loading conditions is needed when studying fatigue strength of implant components. Neverthless, interestingly, both titanium and zirconia abutment materials showed similar fracture strength after cyclic loading.

Zirconia is a densely sintered ceramic that offers chemically stable abutments with improved aesthetics in implant dentistry in combination with all ceramics crowns and FDPs. Yttria-stabilized tetragonal zirconia polycrystal (Y-TZP; zirconia) offers good physical properties, including high flexural strength and high fracture toughness compared to other ceramic materials (Özcan et al., 2013). Unfortunately, the toughness of zirconia could decrease under aging conditions that are mostly related to phase transformation, where the tetragonal $(\mathrm{T})$ phase is transformed into the monoclinic $(\mathrm{M})$ phase. In this transformation, the energy absorbed by the zirconia matrix in the vicinity of the propagating crack is consumed by the $T$ grains to transform into a M symmetry. The progress of the transformation leads to grain pullout and surface 
degradation, by the applied stresses, leading eventually to the failure of the device enhanced by the aqueous environment. Hence, dynamic loading could be anticipated to create more aging effect on zirconia compared to titanium. Interestingly, however, a dramatic decrease in the ultimate strength of zirconia was not observed in this sample. One explanation for this could be the abutment connecetion type that compansated for the possible aging factor on zirconia abutment, namely internally connected implant abutments exhibit significantly higher fracture strengths after cyclic loading compared to externally connected ones. In this studied sample, the number of subgroups with internal connections were higher with zirconia $(n=99)$ than that of titanium $(n=48)$. Also, the number of tested abutments with internal connectors $(n=147)$ were more in number than with external ones $(n=18)$.

Stress applied during mastication may range between $441 \mathrm{~N}$ and $981 \mathrm{~N}, 245 \mathrm{~N}$ and $491 \mathrm{~N}, 147 \mathrm{~N}$ and $368 \mathrm{~N}$, and $98 \mathrm{~N}$ and $270 \mathrm{~N}$ in the molar, premolar, canine, and incisor regions, respectively (Vallittu and Könönen 2000). The ultimate goal in measuring load-bearing capacity of materials is to know clinically whether they could endure chewing forces. The mean results of this study indicated values higher than that $400 \mathrm{~N}$. Regardless of the brand, increased number of cyclic loading $\left(>1 \times 10^{-6}\right)$ decreased the fracture strength of all implant components tested, compared to $<1 \times 10^{-6}$.

Based on the high results above the estimated chewing forces, current all-ceramic systems could be designated as favourable materials for posterior indications. On the other hand, from the technical point of view, the magnitude of the applied load with regard to the highest-level force in a fatigue test, should not exceed $50 \%$ of the ultimate strength of the material on trial. Unfortunately, this information was often not available in the references that performed static loading after fatigue.

Future studies should incorporate the fatigue component in the study set-up in order to deduce more clinically relevant information considering the ultimate strength of the material to be tested after fatigue. Clinically sufficient fracture strength values are not known for durable imokant components. The great variation in testing parameters and testing environment would continue to create the confusion in the 
dental literature. Since in the future, new studies are expected to appear in this field, the following items should be disclosed in in vitro studies:

- The abutment type, abutment material, loading conditions (jig dimensions, type, cross-head speed, indenter type, diameter), cyclic loading conditions (medium, temperature, loading magnitude, speed, number of cycles) should be defined precisely.

- The fracture strength data should be presented with confidence intervals, mean, minimum and maximum values with and without cyclic loading together with initial and ultimate fracture strength values.

\section{Conclusions}

From this systematic review study, the following could be concluded:

1. Current studies regarding the fatigue strength of dental implant components should be evaluated cautiously considering the testing conditions. Some more systematic approach especially regarding the testing and reporting fatigue and loading conditions is needed when studying fatigue strength of implant components.

2. Abutment material type (titanium versus zirconia) showed similar fracture strength after cyclic loading.

3. Internally connected implant abutments seem to exhibit significantly higher fracture strengths after cyclic loading compared to externally connected ones. Due to small sample size this conclusion must be considered with caution.

4. Regardless of the brand, increased number of cyclic loading $\left(>1 \times 10^{-6}\right)$ decreased the fracture strength of all implant components tested, compared to $<1 \times 10^{-6}$.

\section{Clinical Relevance}

Internally connected implant abutments in conjunction with both titanium and zirconia abutments seemed to be more favorable considering long term fatigue durability based on the current available literature. Other clinical factors such as patient and site-specific factors, masticatory activity, aesthetic expectations 
which may be compromised by the gingival thickness, should also be considered when selecting abutments on dental implants.

\section{Acknowledgements}

The authors would like to thank Mrs. Dr. M. Gosteli from the main library of the University of Zurich for her assistance with the electronic literature search, Dr. M. Roos for her support with the statistical analysis.

\section{Conflict of interest}

The authors did not have any commercial interest in any of the materials used in this study. 


\section{References}

Alqahtani F, Flinton R. Post fatigue fracture resistance of modified prefabricated zirconia implant abutments. J Prosthet Dent 2014;112:299-305.

Baldissara P, Özcan M, Melilli D, Valandro LF. Effect of cyclic loading on fracture strength and microleakage of a quartz fiber dowel with different adhesive, cement and resin core material combinations. Minerva Stomatol 2010;59: 407-414.

Basílio Mde A, Butignon LE, Arioli Filho J. Effectiveness of screw surface coating on the stability of zirconia abutments after cyclic loading. Int J Oral Maxillofac Implants 2012;27:1061-1067.

Boff LL, Oderich E, Cardoso AC, Magne P. Fatigue resistance and failure mode of adhesively restored custom metal-composite resin premolar implant abutments. Int J Oral Maxillofac Implants 2014;29:364373.

Boggan RS, Strong JT, Misch CE, Bidez MW. Influence of hex geometry and prosthetic table width on static and fatigue strength of dental implants. J Prosthet Dent 1999;82:436-440.

Butignon LE, Basilio Mde A, Pereira Rde P, Arioli Filho JN. Influence of three types of abutments on preload values before and after cyclic loading with structural analysis by scanning electron microscopy. Int J Oral Maxillofac Implants 2013;28:e161-170.

Butz F, Heydecke G, Okutan M, Strub JR. Survival rate, fracture strength and failure mode of ceramic implant abutments after chewing simulation. J Oral Rehabil 2005;32:838-843.

Dittmer MP, Dittmer S, Borchers L, Kohorst P, Stiesch M. Influence of the interface design on the yield force of the implant-abutment complex before and after cyclic mechanical loading. J Prosthodont Res 2012;56:19-24

Foong JK, Judge RB, Palamara JE, Swain MV. Fracture resistancce of titanium and zirconia abutmets: An in vitro study. J Prosthet Dent 2013;109:304-312. 
Freitas AC Jr, Bonfante EA, Martins LM, Silva NR, Marotta L, Coelho PG. Reliability and failure modes of anterior single-unit implant-supported restorations. Clin Oral Implants Res 2012;23:1005-1011

Freitas-Júnior AC, Almeida EO, Bonfante EA, Silva NR, Coelho PG. Reliability and failure modes of internal conical dental implant connections Clin Oral Implants Res 2013;24:97-202.

Freitas-Júnior AC, Rocha EP, Bonfante EA, Almeida EO, Anchieta RB, Martini AP, Assunção WG, Silva NR, Coelho PG. Biomechanical evaluation of internal and external hexagon platform switched implantabutment connections: An in vitro laboratory and three-dimensional finite element analysis. Dent Mater 2012;28:e218-28.

Gehrke P, Dhom G, Brunner J, Wolf D, Degidi M, Piattelli A. Zirconium implant abutments: Fracture strentght and influence of cyclic loading on retaining-screw loosening. Quintessence Int 2006;37:19-26.

Guazzato M, Quach L, Albakry M, Swain MV. Influence of surface and heat treatments on the flexural strength of Y-TZP dental ceramic. J Dent 2005;33:9-18.

Huang HM, Tsai CM, Chang CC, Lin CT, Lee SY. Evaluation of loading coniditons on fatigue-failed implants by fracture surface analysis Int J Oral Maxillofac Implants 2005;20:854-859.

ISO 14801:2007. Dentistry - Implants - Dynamic fatigue test for endosseous dental implants

Kelly JR1, Benetti P, Rungruanganunt P, Bona AD..The slippery slope - Critical perspectives on in vitro research methodologies...Dent Mater 2012;28:41-51.

Khraisat A. Stability of implant-abutment interface with a hexagon-mediate butt joint: failure mode and bending resistance. Clin Implant Dent Relat Res 2005;7:221-228.

Khraisat A, Abu-Hammad O, Dar-Odeh N, Al-Kayed AM. Abutment screw loosening and bending resistance of external hexagon implant system after lateral cyclic loading Clin Implant Dent Relat Res 2004;6:157-164. 
Kohal RJ, Finke HC, Klaus G. Stability of Prototype two-piece Zirconia and titanium implants after artificial Aging: A in Vitro Pilot Study. Clin Implant Dent Relat Res 2009;11:323-329.

Lawn BR, Deng Y, Thompson VP. Use of contact testing in the characterization and design of all-ceramic crownlike layer structures: a review. J Prosthet Dent 2001;86:495-510.

Magne P, Oderich E, Boff LL, Cardoso AC, Belser UC. Fatigue resistance and failure mode of CAD/CAM composite resin implant abutments restored with type III composite resin and porcelain veneers Clin Oral Implants Res 2011;22:1275-1281.

Magne P, Paranhos MP, Burnett LH Jr, Magne M, Belser UC. Fatigue resistance and failure mode of novel-design anterior single-tooth implant restorations: influence of material selection for type III veneers bonded to zirconia abutments. Clin Oral Implants Res 2011;22:195-200.

Magne P, Silva M, Oderich E, Boff LL, Enciso R. Damping behavior of implant-supported restorations. Clin Oral Implants Res 2013;24:143-148.

Mühlemann S, Truninger TC, Stawarczyk B, Hammerle CH, Sailer I. Bending moments of zirconia and titanium implant abutments supporting all-ceramic crowns after aging. Clin Oral Implants Res 2014;25:7481.

Nguyen HQ, Tan KB, Nicholls JI. Load fatigue performance of implant-ceramic abutment combinations. Int J Oral Maxillofac Implants 2009;24:636-646.

Nothdurft FP, Neumann K, Knauber AW. Fracture behavior of zirconia implant abutments is influenced by superstructure geometry. Clin Oral Investig 2014;18:1467-1472.

Oderich E, Boff LL, Cardoso AC, Magne P.Fatigue resistance and failure mode adhesively restored custom implant zirconia abutments. Clin Oral Implants Res 2012;23:1360-1368. 
Özcan M, Melo RM, Souza ROA, Machado JPB, Valandro LF, Botttino MA. Effect of air-particle abrasion protocols on the biaxial flexural strength, surface characteristics and phase transformation of zirconia after cyclic loading. J Mech Behav Biomed Mater 2013;20:19-28.

Perriard J, Wiskott WA, Mellal A, Scherrer SS, Botsis J, Belser UC. Fatigue resistance of ITI implantabutment connectors. A comparison of the starad cone with a novel internally keyed design. Clin Oral Implants Res 2002;13:542-549.

Protopapadaki M, Monaco EA Jr, Kim HI, Davis EL. Comparison of fracture resistance of pressable metal ceramic custom implant abutment with a commercially fabricated CAD/CAM zirconia implant abutment. J Prosthet Dent 2013;110:389-396.

Quek CE, Tan KB, Nicholls JI. Load fatigue Performance of a single-tooth implant abutment system: effect of diameter. Int J Oral Maxillofac Implants 2006;21:929-936.

Quek HC, Tan KB, Nicholls JI. Load fatigue performance of four implant-abutment interface designs: Effect of torque level and implant system. Int J Oral Maxillofac Implants 2008;23:253-262.

Rosentritt M, Hagemann A, Hahnel S, Behr M, Preis V. In vitro performance of zirconia and titanium implant/abutment systems for anterior application.J Dent 2014;42:1019-1026.

Seetoh YL, Tan KB, Chua EK, Quek HC, Nicholls JI. Load fatigue performance of conical implantabutment connections. Int J Oral Maxillofac Implants 2011;26:797-806.

Steinebrunner L, Wolfart S, Ludwig K, Kern M. Implant-abutment interface design affects fatigue and fracture strength of implants Clin Oral Implants Res 2008;19:1276-1284.

Stimmelmayr M, Sagerer S, Erdelt K, Beuer F. In vitro fatigue and fracture strenght testig of one-piece Zircoia implant abutments ad ziconia implant abutmets connected to titanium cores. Int J Oral Maxillofac Implants 2013;28:488-493. 
Strub JR, Gerds T. Fracture strength and failure mode of five different single-tooth imlant-abutment combinations. Int J Prosthodont 2003;16:167-171.

Truninger TC, Stawarczyk B, Leutert CR, Sailer TR, Hammerle CH, Sailer I. Bending moments of zirconia ad titanium abutments with internal and external implant-abutmet connections after aging and chewing simulation. Clin Oral Implants Res 2012;23:12-18.

Vallittu PK, Könönen M. Biomechanical aspects and material properties. In: Karlsson S, Nilner K, Dahl BL, editors. A textbook of fixed prosthodon- tics: the Scandinavian approach. Stockholm: Gothia; 2000. p. 11630. 


\section{Captions to tables and figures:}

\section{Figures:}

Fig. 1 Process of identifying the studies included in the review.

\section{Tables:}

Table 1a-b. Search strategy in a) MEDLINE and b) EMBASE applied for this review. \#: search, MeSH: Medical subjects heading, a thesaurus word.

Table 2. Articles selected for the review that met the inclusion criteria.

Table 3a-b. Cyclic loading a) test parameters and b) fracture strength of implant abutments.

Table 4. Articles excluded after full-text reading that did not met the inclusion criteria. 


\section{Figures:}

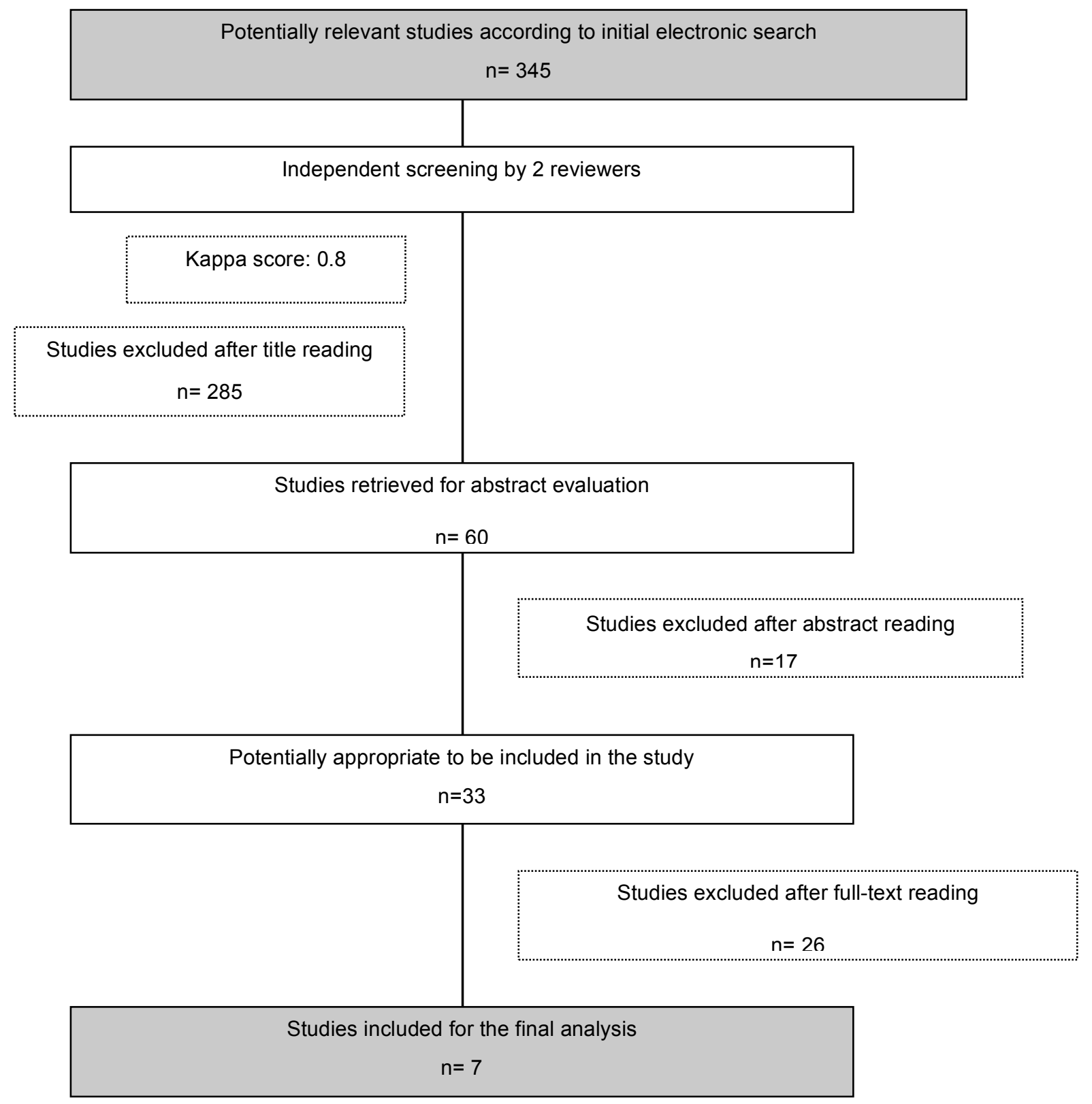

Fig. 1 Process of identifying the studies included in the review. 
Tables:

\begin{tabular}{|c|c|c|}
\hline Search & Literature search strategy & Results \\
\hline 1 & Dental Implants/ & 14082 \\
\hline 2 & dental abutments/ or dental prosthesis, implant-supported/ & 11204 \\
\hline 3 & $\left(\left(\right.\right.$ dental adj3 (implant $^{*}$ or abutment $\left.\left.{ }^{*}\right)\right)$ or (implant adj3 abutment $\left.\left.{ }^{*}\right)\right)$.ti,ab. & 10514 \\
\hline 4 & or/1-3 & 24961 \\
\hline 5 & "Prostheses and Implants"/ or Prosthesis Design/ & 70551 \\
\hline 6 & Implants, Experimental/ & 2561 \\
\hline 7 & (implant or implants or abutment*).ti,ab. & 114482 \\
\hline 8 & or/5-7 & 168313 \\
\hline 9 & (dental or dentistry).ab,jn,kw,ti,sb. & 188672 \\
\hline 10 & 8 and 9 & 13200 \\
\hline 11 & 4 or 10 & 27310 \\
\hline 12 & fatigue.ti,ab. & 60056 \\
\hline 13 & (fracture adj3 resistance).ti,ab. & 1498 \\
\hline 14 & (bending adj3 moments).ti,ab. & 450 \\
\hline 15 & or/12-14 & 61853 \\
\hline 16 & Dental Stress Analysis/ & 13107 \\
\hline 17 & Stress, Mechanical/ & 52099 \\
\hline 18 & 16 or 17 & 52099 \\
\hline 19 & In Vitro/ & 377193 \\
\hline 20 & ("in vitro" or "ex vivo" or experimental or laboratory).ti. & 523726 \\
\hline
\end{tabular}




\begin{tabular}{|c|c|c|}
\hline 21 & $\begin{array}{l}\text { Search ((\#7) AND \#10) Filters: Publication date from 1950/01/01 to 2013/12/31; } \\
\text { English }\end{array}$ & 68 \\
\hline 22 & $\begin{array}{l}\text { Search ((\#7) AND \#11) Filters: Publication date from 1950/01/01 to 2013/12/31; } \\
\text { English }\end{array}$ & 34 \\
\hline 23 & $\begin{array}{l}\text { Search ((\#7) AND \#13) Filters: Publication date from 1950/01/01 to 2013/12/31; } \\
\text { English }\end{array}$ & 9 \\
\hline 24 & $\begin{array}{l}\text { Search ((\#7) AND \#3) Filters: Publication date from 1950/01/01 to 2013/12/31; } \\
\text { English }\end{array}$ & 109 \\
\hline 21 & $\begin{array}{l}\text { (("in vitro" or "ex vivo" or experimental or laboratory) adj3 (experiment or design } \\
\text { or study or test)).ab. }\end{array}$ & 106257 \\
\hline 22 & ((cyclic or simulat $\left.{ }^{\star}\right)$ adj3 (chewing or mastication)).ti,ab. & 267 \\
\hline 23 & ((fracture or cyclic or cylindrical or static) adj3 load*).ti,ab. & 94954 \\
\hline 24 & (external adj3 hexagon adj3 implant).ti,ab. & 109 \\
\hline 25 & or/19-24 & 931577 \\
\hline 26 & or/22-24 & 5181 \\
\hline 27 & 11 and 15 and 25 & 159 \\
\hline 28 & 11 and 18 and 26 & 316 \\
\hline 29 & 27 or 28 & 379 \\
\hline 30 & Osseointegration/ & 7543 \\
\hline 31 & "in situ".ti,ab. & 202588 \\
\hline 32 & 30 or 31 & 210020 \\
\hline 33 & 29 not 32 & 354 \\
\hline 34 & limit 33 to animals & 12 \\
\hline 35 & limit 34 to humans & 1 \\
\hline 36 & 34 not 35 & 11 \\
\hline 37 & 33 not 36 & 343 \\
\hline 38 & limit 37 to english language & 332 \\
\hline
\end{tabular}


Table 1a. Search strategy in MEDLINE applied for this review. \#: search, MeSH: Medical subjects heading, thesaurus word. 


\begin{tabular}{|c|c|c|}
\hline Search & Literature search strategy & Results \\
\hline 1 & $\begin{array}{l}\text { 'tooth implant'/exp OR 'tooth implant' OR 'dental abutment'/exp OR 'dental } \\
\text { abutment' }\end{array}$ & 2920 \\
\hline 2 & 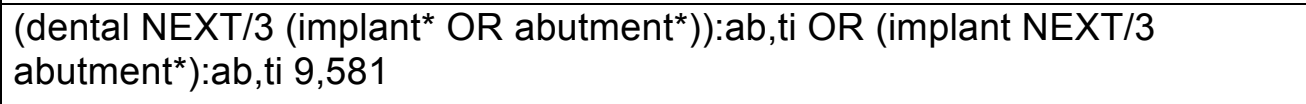 & 9,581 \\
\hline 3 & \#1 OR \#2 & 11214 \\
\hline 4 & implant:ab,ti OR implants:ab,ti OR abutment*:ab,ti & 24961 \\
\hline 5 & dental:de,jt,cl,ab,ti OR dentistry:de,jt,cl,ab,ti & 425,372 \\
\hline 6 & \#4 AND \#5 & 21783 \\
\hline 7 & \#3 OR \#6 & 22,818 \\
\hline 8 & fatigue:ab,ti & 83952 \\
\hline 9 & (fracture NEXT/3 resistance):ab,ti & 1,109 \\
\hline 10 & (bending NEXT/3 moments):ab,ti & 478 \\
\hline 11 & \#8 OR \#9 OR \#10 & 85,423 \\
\hline 12 & 'mechanical stress'/exp & 49,071 \\
\hline 13 & 'in vitro study'/exp OR 'ex vivo study'/exp & $4,208,113$ \\
\hline 14 & 'in vitro':ti OR 'ex vivo':ti OR experimental:ti OR laboratory:ti & 581,645 \\
\hline 15 & $\begin{array}{l}\text { (('in vitro' OR 'ex vivo' OR experimental OR laboratory) NEXT/3 (experiment } \\
\text { OR design OR study OR test)):ab }\end{array}$ & 103,436 \\
\hline 16 & ((cyclic OR simulat*) NEXT/3 (chewing OR mastication)):ab,ti & 114 \\
\hline 17 & ((fracture OR cyclic OR cylindrical OR static) NEXT/3 load*):ab,ti & 4,414 \\
\hline 18 & (external NEXT/3 hexagon):ab,ti & 68 \\
\hline 19 & (hexagon NEXT/3 implant):ab,ti & 37 \\
\hline 20 & \#18 AND \#19 & 31 \\
\hline 21 & \#13 OR \#14 OR \#15 OR \#16 OR \#17 OR \#20 & $4,585,922$ \\
\hline 22 & \#16 OR \#17 OR \#20 & 4,540 \\
\hline 23 & \#7 AND \#11 AND \#21 & 112 \\
\hline 24 & \#7 AND \#12 AND \#22 & 112 \\
\hline 25 & \#23 OR \#24 & 194 \\
\hline
\end{tabular}




\begin{tabular}{|l|l|l|}
\hline $\mathbf{2 6}$ & \#23 OR \#24 AND [animals]/lim & 9 \\
\hline 27 & \#23 OR \#24 AND [animals]/lim AND [humans]/lim & 1 \\
\hline 28 & \#26 NOT \#27 & 8 \\
\hline 29 & \#25 NOT \#28 & 186 \\
\hline 30 & \#25 NOT \#28 AND [english]/lim & 180 \\
\hline
\end{tabular}

Table 1b. Search strategy in EMBASE applied for this review. \#: search, MeSH: Medical subjects heading, thesaurus word. 


\begin{tabular}{|c|c|c|}
\hline $1^{\text {st }}$ author & Title & Publication \\
\hline Boggan RS et al. & $\begin{array}{l}\text { Influence of hex geometry and Propsthetic table width on static } \\
\text { and fatigue stentgth of dental implants }\end{array}$ & J Prosthet Dent 1999;82:436-440. \\
\hline Huang $\mathrm{HM}$ et al. & $\begin{array}{l}\text { Evaluation of loading coniditons on fatigue-failed implants by } \\
\text { fracture surface analysis }\end{array}$ & $\begin{array}{l}\text { Int J Oral Maxillofac Implants } \\
2005 ; 20: 854-859 .\end{array}$ \\
\hline Gehrke P et al. & $\begin{array}{l}\text { Zirconium implant abutments: Fracture strentght and influence of } \\
\text { cyclic loading on retaining-screw loosening }\end{array}$ & Quintessence Int 2006;37:19-26 \\
\hline Dittmer MP et al. & $\begin{array}{l}\text { Influence of the interface design on the yield force of the implant- } \\
\text { abutment complex before and after cyclic mechanical loading }\end{array}$ & J Prosthodont Res 2012;56:19-24. \\
\hline Truninger TC et al. & $\begin{array}{l}\text { Bending moments of zirconia ad titanium abutments with internal } \\
\text { and external implant-abutmet connections after aging and } \\
\text { chewing simulation }\end{array}$ & Clin Oral Implants Res 2012;23:12-18. \\
\hline Stimmelmayr M et al. & $\begin{array}{l}\text { In vitro fatigue and fracture strenght testig of one-piece Zircoia } \\
\text { implant abutments ad ziconia implant abutmets connected to } \\
\text { titanium cores }\end{array}$ & $\begin{array}{l}\text { Int J Oral Maxillofac Implants } \\
\text { 2013;28:488-493. }\end{array}$ \\
\hline Alqahtani F et al. & $\begin{array}{l}\text { Postfatigue fracture resistance of modified prefabricated zirconia } \\
\text { implant abutments }\end{array}$ & J Prosthet Dent 2014;112:299-305. \\
\hline
\end{tabular}

Table 2. Articles selected for the review that met the inclusion criteria. 


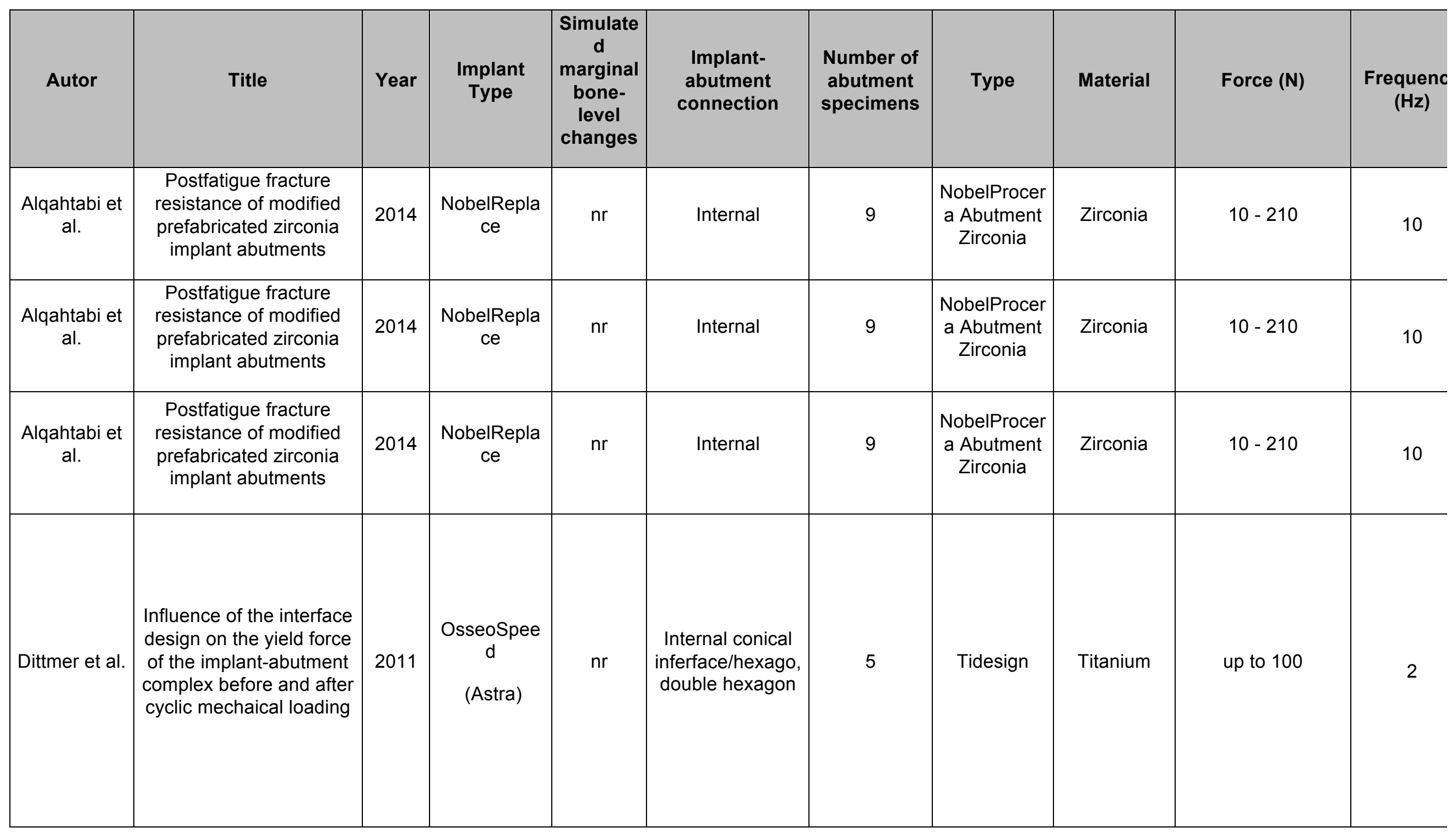




\begin{tabular}{|c|c|c|c|c|c|c|c|c|c|c|}
\hline Dittmer et al. & $\begin{array}{l}\text { Influence of the interface } \\
\text { design on the yield force } \\
\text { of the implant-abutment } \\
\text { complex before and after } \\
\text { cyclic mechaical loading }\end{array}$ & 2011 & $\begin{array}{l}\text { Semados } \\
\text { (Bego) }\end{array}$ & $\mathrm{nr}$ & $\begin{array}{l}\text { Hey-index flat to } \\
\text { flat connextion } \\
\text { with short interal } \\
\text { conical matrix) }\end{array}$ & 5 & $\begin{array}{c}\text { Sub-Tec Ti- } \\
\text { Abutment }\end{array}$ & Titanium & up to 100 & 2 \\
\hline Dittmer et al. & $\begin{array}{l}\text { Influence of the interface } \\
\text { design on the yield force } \\
\text { of the implant-abutment } \\
\text { complex before and after } \\
\text { cyclic mechaical loading }\end{array}$ & 2011 & $\begin{array}{l}\text { Screw-line } \\
\text { promote } \\
\text { plus } \\
\text { (Camlog) }\end{array}$ & $\mathrm{nr}$ & $\begin{array}{l}\text { Butt-joint/3 } \\
\text { possible } \\
\text { positions }\end{array}$ & 5 & $\begin{array}{c}\text { Universal } \\
\text { abutment } \\
11 \mathrm{~mm}\end{array}$ & Titanium & up to 100 & 2 \\
\hline Dittmer et al. & $\begin{array}{l}\text { Influence of the interface } \\
\text { design on the yield force } \\
\text { of the implant-abutment } \\
\text { complex before and after } \\
\text { cyclic mechaical loading }\end{array}$ & 2011 & $\begin{array}{c}\text { Akylos plus } \\
\text { B14 } \\
\text { (Friadent) }\end{array}$ & $\mathrm{nr}$ & $\begin{array}{l}\text { Iternal conical } \\
\text { inferface/no } \\
\text { index }\end{array}$ & 5 & $\begin{array}{c}\text { Balance } \\
\text { posterior } \\
0.75\end{array}$ & Titanium & up to 100 & 2 \\
\hline Dittmer et al. & $\begin{array}{l}\text { Influence of the interface } \\
\text { design on the yield force } \\
\text { of the implant-abutment } \\
\text { complex before and after } \\
\text { cyclic mechaical loading }\end{array}$ & 2011 & $\begin{array}{c}\text { MK III } \\
\text { Groovy RP } \\
\text { (Nobel } \\
\text { Biocare) }\end{array}$ & $\mathrm{nr}$ & $\begin{array}{c}\text { Hex-inedxed } \\
\text { butt-joint }\end{array}$ & 5 & $\begin{array}{c}\text { Easy } \\
\text { abutmet } \\
\text { Bmk syst Rp } \\
1 \mathrm{~mm}\end{array}$ & Titanium & up to 100 & 2 \\
\hline Dittmer et al. & $\begin{array}{l}\text { Influence of the interface } \\
\text { design on the yield force } \\
\text { of the implant-abutment } \\
\text { complex before and after } \\
\text { cyclic mechaical loading }\end{array}$ & 2011 & $\begin{array}{c}\text { Standard } \\
\text { implant } \\
\text { (Straumann) }\end{array}$ & $\mathrm{nr}$ & $\begin{array}{c}\text { internal conical } \\
\text { interface/octagon }\end{array}$ & 5 & $\begin{array}{l}\text { RN synOcta } \\
\text { Tiabutment }\end{array}$ & Titanium & up to 100 & 2 \\
\hline
\end{tabular}




\begin{tabular}{|c|c|c|c|c|c|c|c|c|c|c|}
\hline Gehrke et al. & $\begin{array}{l}\text { Zirconium implant } \\
\text { abutments: Fracture } \\
\text { strentght and influence of } \\
\text { cyclic loading on } \\
\text { retaining-screw } \\
\text { loosening }\end{array}$ & 2006 & \begin{tabular}{|c} 
XiVE \\
implants \\
(Dentsply/Fri \\
adent)
\end{tabular} & $3 \mathrm{~mm}$ & internally hexed & 7 & $\begin{array}{l}\text { Cercon } \\
\text { zirconium } \\
\text { implant } \\
\text { abutments } \\
\text { (Dentsply/Fr } \\
\text { iadent) }\end{array}$ & Zirconia & $100-450$ & 15 \\
\hline Huang et al. & $\begin{array}{l}\text { Evaluation of loading } \\
\text { coniditons on fatigue- } \\
\text { failed implants by } \\
\text { fracture surface analysis }\end{array}$ & 2005 & $\begin{array}{l}\text { BioTech } \\
\text { One Pure } \\
\text { titanium } \\
\text { implants }\end{array}$ & $\mathrm{nr}$ & $\mathrm{nr}$ & 35 & $\begin{array}{l}\text { cylindric } \\
\text { abutment } \\
\text { BioTech } \\
\text { One }\end{array}$ & Titanium & $319.52-718.92$ & 15 \\
\hline $\begin{array}{c}\text { Stimmelmay } \\
\text { r et al. }\end{array}$ & $\begin{array}{l}\text { In vitro fatigue and } \\
\text { fracture strenght testig of } \\
\text { one-piece Zircoia implant } \\
\text { abutments ad ziconia } \\
\text { implant abutmets } \\
\text { connected to titanium } \\
\text { cores }\end{array}$ & 2013 & \begin{tabular}{|} 
Bego- \\
Semados S \\
(BEGO \\
Implant) \\
Systems \\
Diameter \\
$3.75 \mathrm{~mm}$
\end{tabular} & $\mathrm{nr}$ & Internal hex & 8 & $\begin{array}{l}\text { BeCe CAD } \\
\text { Zircon HX, } \\
\text { BEGO } \\
\text { Implant } \\
\text { Systems }\end{array}$ & Zirconia & 120 & 1.2 \\
\hline $\begin{array}{c}\text { Stimmelmay } \\
r \text { et al. }\end{array}$ & $\begin{array}{l}\text { In vitro fatigue and } \\
\text { fracture strenght testig of } \\
\text { one-piece Zircoia implant } \\
\text { abutments ad ziconia } \\
\text { implant abutmets } \\
\text { connected to titanium } \\
\text { cores }\end{array}$ & 2013 & \begin{tabular}{|} 
Bego- \\
Semados S \\
(BEGO \\
Implant) \\
Systems \\
Diameter \\
$3.75 \mathrm{~mm}$
\end{tabular} & $\mathrm{nr}$ & Internal hex & 8 & $\begin{array}{l}\text { BeCe CAD } \\
\text { Zircon HX, } \\
\text { BEGO } \\
\text { Implant } \\
\text { Systems }\end{array}$ & $\begin{array}{l}\text { Zirconia on } \\
\text { titanium } \\
\text { core } \\
\text { (Titanium- } \\
\text { aluminium- } \\
\text { vanadium- } \\
\text { alloy) }\end{array}$ & 120 & 1.2 \\
\hline
\end{tabular}




\begin{tabular}{|c|c|c|c|c|c|c|c|c|c|c|}
\hline $\begin{array}{c}\text { Stimmelmay } \\
\text { r et al. }\end{array}$ & $\begin{array}{l}\text { In vitro fatigue and } \\
\text { fracture strenght testig of } \\
\text { one-piece Zircoia implant } \\
\text { abutments ad ziconia } \\
\text { implant abutmets } \\
\text { connected to titanium } \\
\text { cores }\end{array}$ & 2013 & $\begin{array}{c}\text { Bego- } \\
\text { Semados S } \\
\text { (BEGO } \\
\text { Implant } \\
\text { Systems) } \\
\text { Diameter } \\
5.5 \mathrm{~mm}\end{array}$ & $\mathrm{nr}$ & Internal hex & 8 & $\begin{array}{c}\text { BeCe CAD } \\
\text { Zircon HX, } \\
\text { BEGO } \\
\text { Implant } \\
\text { Systems }\end{array}$ & Zirconia & 120 & 1.2 \\
\hline $\begin{array}{l}\text { Stimmelmay } \\
\text { r et al. }\end{array}$ & $\begin{array}{l}\text { In vitro fatigue and } \\
\text { fracture strenght testig of } \\
\text { one-piece Zircoia implant } \\
\text { abutments ad ziconia } \\
\text { implant abutmets } \\
\text { connected to titanium } \\
\text { cores }\end{array}$ & 2013 & $\begin{array}{l}\text { Bego- } \\
\text { Semados S } \\
\text { (BEGO } \\
\text { Implant } \\
\text { Systems) } \\
\text { Diameter } \\
5.5 \mathrm{~mm}\end{array}$ & $\mathrm{nr}$ & Internal hex & 8 & $\begin{array}{c}\text { BeCe CAD } \\
\text { Zircon HX, } \\
\text { BEGO } \\
\text { Implant } \\
\text { Systems }\end{array}$ & $\begin{array}{l}\text { Zirconia on } \\
\text { titanium } \\
\quad \text { core } \\
\text { (Titanium- } \\
\text { aluminium- } \\
\text { vanadium- } \\
\quad \text { alloy) }\end{array}$ & 120 & 1.2 \\
\hline $\begin{array}{c}\text { Truninger et } \\
\text { al. }\end{array}$ & $\begin{array}{l}\text { Bending moments of } \\
\text { zirconia ad titanium } \\
\text { abutments with internal } \\
\text { and external implant- } \\
\text { abutmet connections } \\
\text { after aging and chewing } \\
\text { simulation }\end{array}$ & 2010 & $\begin{array}{c}\text { Bonelevel } \\
\text { RC implants } \\
\text { (Straumann) }\end{array}$ & $\begin{array}{c}3 \mathrm{~mm} \\
\text { vertical } \\
\text { bone } \\
\text { loss } \\
\text { simulate } \\
\mathrm{d}\end{array}$ & internal & 12 & $\begin{array}{l}\text { ETKON } \\
\text { one-piece } \\
\text { internal } \\
\text { implant- } \\
\text { abutment } \\
\text { connection }\end{array}$ & Zirconia & 49 & 1.67 \\
\hline
\end{tabular}




\begin{tabular}{|c|c|c|c|c|c|c|c|c|c|c|}
\hline $\begin{array}{c}\text { Truninger et } \\
\text { al. }\end{array}$ & $\begin{array}{l}\text { Bending moments of } \\
\text { zirconia ad titanium } \\
\text { abutments with internal } \\
\text { and external implant- } \\
\text { abutmet connections } \\
\text { after aging and chewing } \\
\text { simulation }\end{array}$ & 2010 & $\begin{array}{l}\text { Replace- } \\
\text { Select } \\
\text { system } \\
\text { (Nobel } \\
\text { Biocare) }\end{array}$ & $\begin{array}{l}3 \mathrm{~mm} \\
\text { vertical } \\
\text { bone } \\
\text { loss } \\
\text { simulate } \\
\text { d }\end{array}$ & Internal & 12 & $\begin{array}{l}\text { Procera } \\
\text { abutments } \\
\text { internal } \\
\text { implant- } \\
\text { abutment } \\
\text { connection }\end{array}$ & Zirconia & 49 & 1.67 \\
\hline $\begin{array}{c}\text { Truninger et } \\
\text { al. }\end{array}$ & $\begin{array}{l}\text { Bending moments of } \\
\text { zirconia ad titanium } \\
\text { abutments with internal } \\
\text { and external implant- } \\
\text { abutmet connections } \\
\text { after aging and chewing } \\
\text { simulation }\end{array}$ & 2010 & $\begin{array}{l}\text { Branemark } \\
\text { MKIII RP } \\
\text { Implants } \\
\text { (Nobel } \\
\text { Biocare) }\end{array}$ & $\begin{array}{l}3 \mathrm{~mm} \\
\text { vertical } \\
\text { bone } \\
\text { loss } \\
\text { simulate } \\
\text { d }\end{array}$ & external hexagon & 12 & $\begin{array}{l}\text { Procera } \\
\text { abutments } \\
\text { external } \\
\text { implant- } \\
\text { abutment } \\
\text { connection }\end{array}$ & Zirconia & 49 & 1.67 \\
\hline $\begin{array}{c}\text { Truninger et } \\
\text { al. }\end{array}$ & $\begin{array}{l}\text { Bending moments of } \\
\text { zirconia ad titanium } \\
\text { abutments with internal } \\
\text { and external implant- } \\
\text { abutmet connections } \\
\text { after aging and chewing } \\
\text { simulation }\end{array}$ & 2010 & $\begin{array}{c}\text { Standart } \\
\text { Plus RN } \\
\text { implants } \\
\text { (Straumann) }\end{array}$ & $\begin{array}{l}3 \mathrm{~mm} \\
\text { vertical } \\
\text { bone } \\
\text { loss } \\
\text { simulate } \\
\text { d }\end{array}$ & internal & 12 & $\begin{array}{l}\text { CARES } \\
\text { abutments } \\
\text { with internal } \\
\text { implant- } \\
\text { abutment } \\
\text { connection }\end{array}$ & Zirconia & 49 & 1.67 \\
\hline $\begin{array}{c}\text { Truninger et } \\
\text { al. }\end{array}$ & $\begin{array}{l}\text { Bending moments of } \\
\text { zirconia ad titanium } \\
\text { abutments with internal } \\
\text { and external implant- } \\
\text { abutmet connections } \\
\text { after aging and chewing } \\
\text { simulation }\end{array}$ & 2010 & $\begin{array}{c}\text { Bonelevel } \\
\text { RC implants } \\
\text { (Straumann) }\end{array}$ & $\begin{array}{l}3 \mathrm{~mm} \\
\text { vertical } \\
\text { bone } \\
\text { loss } \\
\text { simulate } \\
\text { d }\end{array}$ & internal & 12 & $\begin{array}{l}\text { CARES } \\
\text { abutments } \\
\text { with one- } \\
\text { piece } \\
\text { internal } \\
\text { implant- } \\
\text { abutment } \\
\text { connection }\end{array}$ & Titanium & 49 & 1.67 \\
\hline $\begin{array}{l}\text { Boggan et } \\
\text { al. }\end{array}$ & $\begin{array}{l}\text { Influence of hex } \\
\text { geometry and } \\
\text { Propsthetic table width } \\
\text { on static and fatigue } \\
\text { stentgth of dental } \\
\text { implants }\end{array}$ & 1999 & $\begin{array}{c}\text { Maestro } \\
\text { implant } \\
\text { system } 4 \mathrm{~mm} \\
\text { (BioHorizon } \\
\text { s Implantat } \\
\text { Systems) }\end{array}$ & $\mathrm{nr}$ & external hexagon & 3 & Maestro & Titanium & $96.6-966$ & 15 \\
\hline
\end{tabular}




\begin{tabular}{|c|c|c|c|c|c|c|c|c|}
\hline $\begin{array}{c}\text { Bnfluence of hex } \\
\text { geometry and } \\
\text { al. }\end{array}$ & $\begin{array}{c}\text { Propsthetic table width } \\
\text { on static and fatigue } \\
\text { stentgth of dental } \\
\text { implants }\end{array}$ & 1999 & $\begin{array}{c}\text { Maestro } \\
\text { implant } \\
\text { system 5mm } \\
\text { (BioHorizon } \\
\text { s Implantat } \\
\text { Systems) }\end{array}$ & $\mathrm{nr}$ & external hexagon & 3 & Maestro & Titanium \\
\hline
\end{tabular}

Table 3a. Cyclic loading test parameters for implant abutments. 


\begin{tabular}{|c|c|c|c|c|c|c|c|c|c|c|}
\hline 1st Author & Modifications & $\begin{array}{l}\text { Fracture } \\
\text { strength } \\
\text { (N) before } \\
\text { fatigue }\end{array}$ & $\begin{array}{l}\text { Number } \\
\text { of cyclic } \\
\text { loading }\end{array}$ & $\begin{array}{l}\text { Temper } \\
\text { ature }\end{array}$ & Environment & $\begin{array}{l}\text { Load } \\
\text { application } \\
\text { axis }\end{array}$ & Indenter & Testing device & $\begin{array}{c}\text { Fracture } \\
\text { strength }(\mathrm{N}) \\
\text { after fatigue } \pm \\
\text { SD }\end{array}$ & $\begin{array}{c}\text { Cross- } \\
\text { head } \\
\text { speed } \\
(\mathrm{mm} / \mathrm{min})\end{array}$ \\
\hline $\begin{array}{l}\text { Alqahtabi et } \\
\text { al. }\end{array}$ & Unprepared & $\mathrm{nr}$ & 250.000 & $\mathrm{nr}$ & $\begin{array}{l}\text { moist (saliva } \\
\text { substitute) }\end{array}$ & $\begin{array}{l}45^{\circ} \text { off to } \\
\text { axis }^{\circ}\end{array}$ & $\mathrm{nr}$ & ADMET & $567 \pm 35.4$ & 1 \\
\hline $\begin{array}{c}\text { Alqahtabi et } \\
\text { al. }\end{array}$ & $\begin{array}{l}1 \mathrm{~mm} \text { apical } \\
\text { reduction/0.8 } \\
\mathrm{mm} \text { chamfer }\end{array}$ & $\mathrm{nr}$ & 250.000 & $\mathrm{nr}$ & $\begin{array}{l}\text { moist (saliva } \\
\text { substitute) }\end{array}$ & $\begin{array}{l}45^{\circ} \text { off to } \\
\text { axis }^{\circ}\end{array}$ & $\mathrm{nr}$ & ADMET & $445.4 \pm 41$ & 1 \\
\hline $\begin{array}{c}\text { Alqahtabi et } \\
\text { al. }\end{array}$ & $\begin{array}{l}1.5 \mathrm{~mm} \text { apical } \\
\text { reduction/0.8 } \\
\mathrm{mm} \text { chamfer }\end{array}$ & $\mathrm{nr}$ & 250.000 & $\mathrm{nr}$ & $\begin{array}{l}\text { moist (saliva } \\
\text { substitute) }\end{array}$ & $\begin{array}{l}45^{\circ} \text { off to } \\
\text { axis }^{\circ}\end{array}$ & $\mathrm{nr}$ & ADMET & $430.5 \pm 39.4$ & 1 \\
\hline Dittmer et al. & unmodified & $430 \pm 59$ & 1.000 .000 & $\mathrm{nr}$ & $\begin{array}{c}\text { moist } \\
\text { (lubricant film) }\end{array}$ & $\begin{array}{l}30^{\circ} \text { off to } \\
\text { axis }\end{array}$ & $\begin{array}{c}\text { hemispherical } \\
\text { loading device } \\
\text { (cobalt- } \\
\text { chromium) }\end{array}$ & $\begin{array}{c}\text { 20K UTS } \\
\text { Testsysteme }\end{array}$ & $394 \pm 19$ & 1 \\
\hline Dittmer et al. & unmodified & $955 \pm 296$ & 1.000 .000 & $\mathrm{nr}$ & $\begin{array}{c}\text { moist } \\
\text { (lubricant film) }\end{array}$ & $\begin{array}{l}30^{\circ} \text { off to } \\
\text { axis }\end{array}$ & $\begin{array}{c}\text { hemispherical } \\
\text { loading device } \\
\text { (cobalt- } \\
\text { chromium) }\end{array}$ & $\begin{array}{c}\text { 20K UTS } \\
\text { Testsysteme }\end{array}$ & $407 \pm 65$ & 1 \\
\hline Dittmer et al. & unmodified & $891 \pm 85$ & 1.000 .000 & $\mathrm{nr}$ & $\begin{array}{c}\text { moist } \\
\text { (lubricant film) }\end{array}$ & $\begin{array}{l}30^{\circ} \text { off to } \\
\text { axis }\end{array}$ & $\begin{array}{c}\text { hemispherical } \\
\text { loading device } \\
\text { (cobalt- } \\
\text { chromium) }\end{array}$ & $\begin{array}{c}\text { 20K UTS } \\
\text { Testsysteme }\end{array}$ & $378 \pm 165$ & 1 \\
\hline
\end{tabular}

\begin{tabular}{|c|c|c|c|c|c|c|c|c|c|}
\hline Dittmer et al. & unmodified & $369 \pm 73$ & 1.000 .000 & $\mathrm{nr}$ & $\begin{array}{c}\text { moist } \\
\text { (lubricant film) }\end{array}$ & $\begin{array}{c}30^{\circ} \text { off to } \\
\text { axis }\end{array}$ & $\begin{array}{c}\text { hemispherical } \\
\text { loading device } \\
\text { (cobalt- }\end{array}$ & $\begin{array}{c}20 \mathrm{~K} \text { UTS } \\
\text { Testsysteme }\end{array}$ & $\begin{array}{c}304 \pm 9 \\
1\end{array}$ \\
\hline
\end{tabular}




\begin{tabular}{|c|c|c|c|c|c|c|c|c|c|c|}
\hline & & & & & & & chromium) & & & \\
\hline Dittmer et al. & unmodified & $635 \pm 313$ & 1.000 .000 & $\mathrm{nr}$ & $\begin{array}{c}\text { moist } \\
\text { (lubricant film) }\end{array}$ & $\begin{array}{l}30^{\circ} \text { off to } \\
\text { axis }\end{array}$ & $\begin{array}{c}\text { hemispherical } \\
\text { loading device } \\
\text { (cobalt- } \\
\text { chromium) }\end{array}$ & $\begin{array}{c}\text { 20K UTS } \\
\text { Testsysteme }\end{array}$ & $347 \pm 24$ & 1 \\
\hline Dittmer et al. & unmodified & $456 \pm 54$ & 1.000 .000 & $\mathrm{nr}$ & $\begin{array}{c}\text { moist } \\
\text { (lubricant film) }\end{array}$ & $\begin{array}{l}30^{\circ} \text { off to } \\
\text { axis }\end{array}$ & $\begin{array}{c}\text { hemispherical } \\
\text { loading device } \\
\text { (cobalt- } \\
\text { chromium) }\end{array}$ & $\begin{array}{c}20 \mathrm{~K} \text { UTS } \\
\text { Testsysteme }\end{array}$ & $397 \pm 43$ & 1 \\
\hline Gehrke et al. & unmodified & 672 & $\begin{array}{c}5.0000 .00 \\
0\end{array}$ & $\mathrm{nr}$ & $\mathrm{nr}$ & $\begin{array}{l}30^{\circ} \text { off to } \\
\text { axis }\end{array}$ & $\begin{array}{l}\text { stainless steel } \\
\text { rod }\end{array}$ & $\begin{array}{l}\text { Instron } 8872 \\
\text { Instron }\end{array}$ & $268.8 \pm 37.8$ & 1.27 \\
\hline Huang et al. & unmodified & $798.8 \pm 4.1$ & $\begin{array}{c}5.0000 .00 \\
0\end{array}$ & $\mathrm{nr}$ & $\mathrm{nr}$ & $\begin{array}{l}30^{\circ} \text { off to } \\
\text { axis }\end{array}$ & $\mathrm{nr}$ & $\begin{array}{l}\text { 858 MiniBionix } \\
\text { Axial Torsional } \\
\text { Test System; } \\
\text { MTS System }\end{array}$ & $459.31 \pm 29.9$ & 3 \\
\hline $\begin{array}{l}\text { Stimmelmayr } \\
\text { et al. }\end{array}$ & unmodified & $\mathrm{nr}$ & 100.000 & $5^{\circ}$ to $55^{\circ}$ & $\mathrm{nr}$ & $\begin{array}{l}30^{\circ} \text { off to } \\
\text { axis }\end{array}$ & $\begin{array}{l}\text { roud stainless- } \\
\text { steel stylus }\end{array}$ & $\begin{array}{c}\text { CS-4, SD } \\
\text { Mechtronic } \\
\text { beim Dynamic } \\
\text { loading oder } \\
1445, \\
\text { Zwick/Roell bei } \\
\text { fracture stregth } \\
\text { testing }\end{array}$ & $526 \pm 32$ & 0.5 \\
\hline $\begin{array}{l}\text { Stimmelmayr } \\
\text { et al. }\end{array}$ & unmodified & $\mathrm{nr}$ & 100.000 & $5^{\circ}$ to $55^{\circ}$ & $\mathrm{nr}$ & $\begin{array}{l}30^{\circ} \text { off to } \\
\text { axis }\end{array}$ & $\begin{array}{l}\text { roud stainless- } \\
\text { steel stylus }\end{array}$ & $\begin{array}{c}\text { CS-4, SD } \\
\text { Mechtronic } \\
\text { beim Dynamic } \\
\text { loading oder } \\
1445, \\
\text { Zwick/Roell bei } \\
\text { fracture stregth } \\
\text { testing }\end{array}$ & $1241 \pm 268$ & 0.5 \\
\hline $\begin{array}{l}\text { Stimmelmayr } \\
\text { et al. }\end{array}$ & unmodified & $\mathrm{nr}$ & 100.000 & $5^{\circ}$ to $55^{\circ}$ & $\mathrm{nr}$ & $\begin{array}{l}30^{\circ} \text { off to } \\
\text { axis }\end{array}$ & $\begin{array}{l}\text { roud stainless- } \\
\text { steel stylus }\end{array}$ & $\begin{array}{c}\text { CS-4, SD } \\
\text { Mechtronic } \\
\text { beim Dynamic } \\
\text { loading oder } \\
1445, \\
\text { Zwick/Roell bei }\end{array}$ & $1894 \pm 137$ & 0.5 \\
\hline
\end{tabular}




\begin{tabular}{|c|c|c|c|c|c|c|c|c|c|c|}
\hline & & & & & & & & $\begin{array}{c}\text { fracture stregth } \\
\text { testing }\end{array}$ & & \\
\hline $\begin{array}{c}\text { Stimmelmayr } \\
\text { et al. }\end{array}$ & unmodified & $\mathrm{nr}$ & 100.000 & $5^{\circ}$ to $55^{\circ}$ & $\mathrm{nr}$ & $\begin{array}{l}30^{\circ} \text { off to } \\
\text { axis }\end{array}$ & $\begin{array}{l}\text { roud stainless- } \\
\text { steel stylus }\end{array}$ & \begin{tabular}{|c|} 
CS-4, SD \\
Mechtronic \\
beim Dynamic \\
loading oder \\
1445, \\
Zwick/Roell bei \\
fracture stregth \\
testing
\end{tabular} & $2225 \pm 63$ & 0.5 \\
\hline $\begin{array}{c}\text { Truninger et } \\
\text { al. }\end{array}$ & unmodified & $\mathrm{nr}$ & $\begin{array}{c}12.000 .00 \\
0\end{array}$ & $5-50^{\circ}$ & wasser & $\begin{array}{l}30^{\circ} \text { off to } \\
\text { axis }\end{array}$ & $\begin{array}{c}\text { corrosionfree } \\
\text { steel indenter } \\
\text { with rounded tip } \\
(\mathrm{ST} \text { V4A) }\end{array}$ & $\begin{array}{l}\text { Zwick/Roell } \\
\text { Z010, Zwick }\end{array}$ & $663.4 \pm 105.6$ & 1 \\
\hline
\end{tabular}

\begin{tabular}{|c|c|c|c|c|c|c|c|c|c|c|}
\hline $\begin{array}{c}\text { Truninger et } \\
\text { al. }\end{array}$ & unmodified & $\mathrm{nr}$ & $\begin{array}{c}12.000 .00 \\
0\end{array}$ & $5-50^{\circ}$ & wasser & $\begin{array}{l}30^{\circ} \text { off to } \\
\text { axis }\end{array}$ & $\begin{array}{c}\text { corrosionfree } \\
\text { steel indenter } \\
\text { with rounded tip } \\
\text { (ST V4A) }\end{array}$ & $\begin{array}{l}\text { Zwick/Roell } \\
\text { Z010, Zwick }\end{array}$ & $859.4 \pm 125.6$ & 1 \\
\hline $\begin{array}{c}\text { Truninger et } \\
\text { al. }\end{array}$ & unmodified & $\mathrm{nr}$ & $\begin{array}{c}12.000 .00 \\
0\end{array}$ & $5-50^{\circ}$ & wasser & $\begin{array}{l}30^{\circ} \text { off to } \\
\text { axis }\end{array}$ & $\begin{array}{c}\text { corrosionfree } \\
\text { steel indenter } \\
\text { with rounded tip } \\
\text { (ST V4A) }\end{array}$ & $\begin{array}{l}\text { Zwick/Roell } \\
\text { Z010, Zwick }\end{array}$ & $571.6 \pm 128.8$ & 1 \\
\hline $\begin{array}{c}\text { Truninger et } \\
\text { al. }\end{array}$ & unmodified & $\mathrm{nr}$ & $\begin{array}{c}12.000 .00 \\
0\end{array}$ & $5-50^{\circ}$ & wasser & $\begin{array}{l}30^{\circ} \text { off to } \\
\text { axis }\end{array}$ & $\begin{array}{c}\text { corrosionfree } \\
\text { steel indenter } \\
\text { with rounded tip } \\
\text { (ST V4A) }\end{array}$ & $\begin{array}{l}\text { Zwick/Roell } \\
\text { Z010, Zwick }\end{array}$ & $759.8 \pm 118.2$ & 1 \\
\hline $\begin{array}{c}\text { Truninger et } \\
\text { al. }\end{array}$ & unmodified & $\mathrm{nr}$ & $\begin{array}{c}12.000 .00 \\
0\end{array}$ & $5-50^{\circ}$ & wasser & $\begin{array}{l}30^{\circ} \text { off to } \\
\text { axis }\end{array}$ & $\begin{array}{c}\text { corrosionfree } \\
\text { steel indenter } \\
\text { with rounded tip } \\
\text { (ST V4A) }\end{array}$ & $\begin{array}{l}\text { Zwick/Roell } \\
\text { Z010, Zwick }\end{array}$ & $1428.2 \pm 369.8$ & 1 \\
\hline Boggan et al. & \begin{tabular}{|c|} 
costomized, not \\
specified, 2.7 \\
mm diameter
\end{tabular} & $966 \pm 7.6$ & $\begin{array}{c}\text { Testing } \\
\text { until } \\
\text { fracture }\end{array}$ & $37^{\circ}$ & $0.9 \%$ saline & $\begin{array}{l}30^{\circ} \text { off to } \\
\text { axis }\end{array}$ & $\mathrm{nr}$ & $\begin{array}{l}\text { servohydraulic } \\
\text { test machine }\end{array}$ & $350 \pm 57.7$ & 0.51 \\
\hline
\end{tabular}




\begin{tabular}{|l|l|l|c|c|c|c|c|c|c|}
\hline Boggan et al. & $\begin{array}{c}\text { costomized, not } \\
\text { specified, } 3 \mathrm{~mm} \\
\text { diameter }\end{array}$ & $1955 \pm 18.2$ & $\begin{array}{c}\text { Testing } \\
\text { until } \\
\text { fracture }\end{array}$ & $37^{\circ}$ & $0.9 \%$ saline & $\begin{array}{c}30^{\circ} \text { off to } \\
\text { axis }\end{array}$ & nr & $\begin{array}{c}\text { servohydraulic } \\
\text { test machine }\end{array}$ & $625 \pm 57.7$ \\
\hline
\end{tabular}

Table 3b. Cyclic loading test parameters applied for testing implant abutments and fracture strength values. 


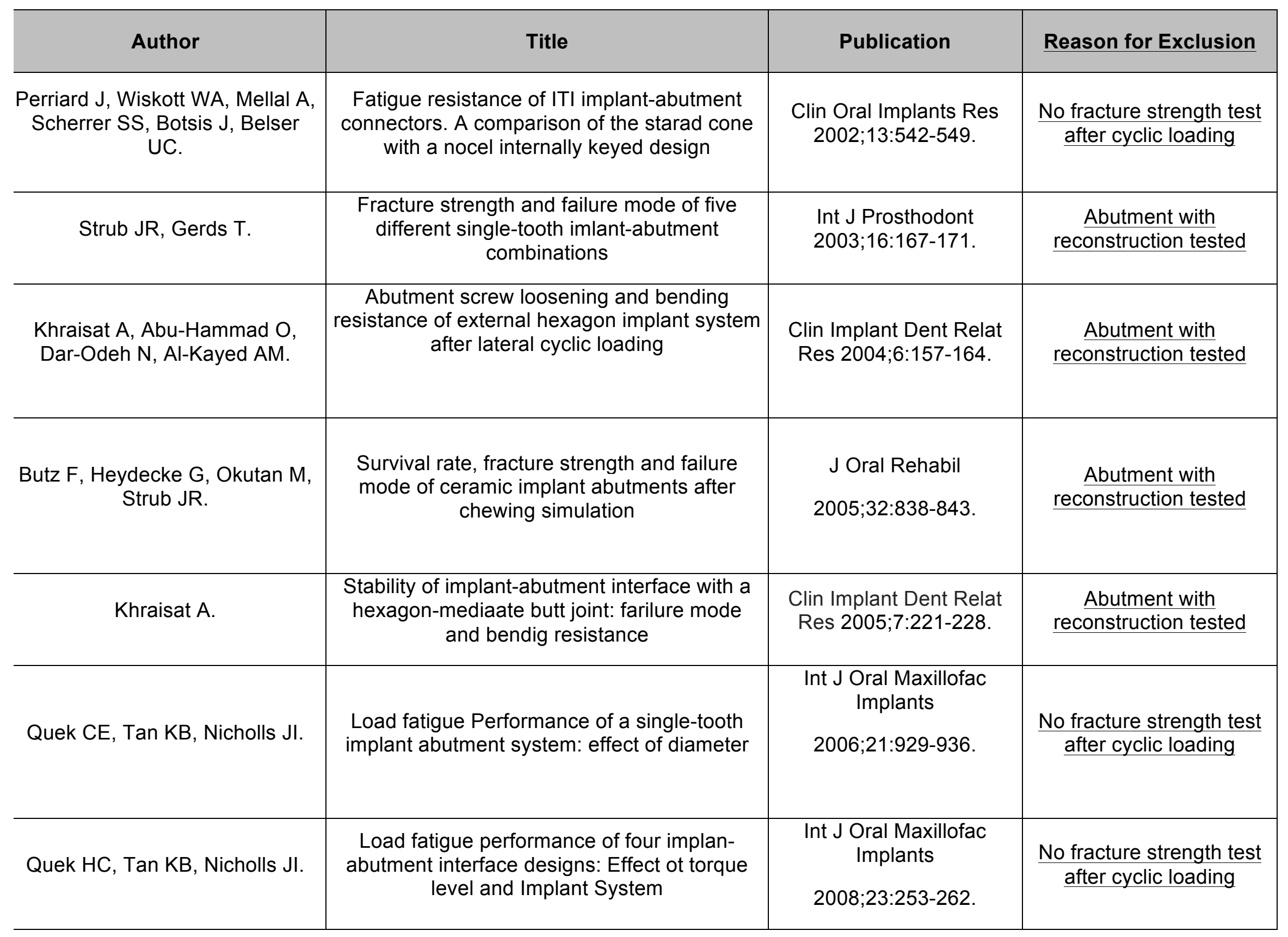




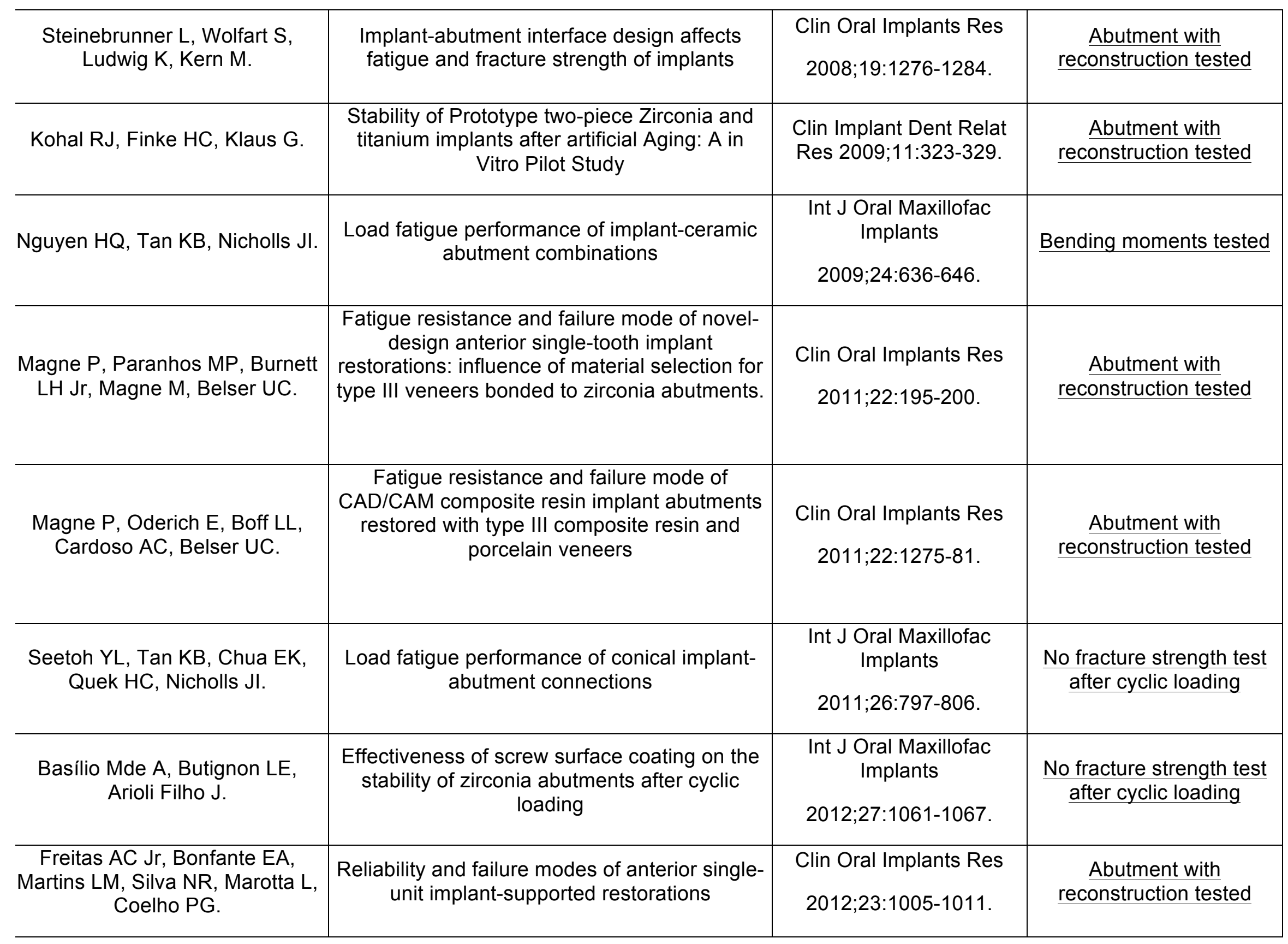




\begin{tabular}{|c|c|c|c|}
\hline $\begin{array}{c}\text { Freitas-Júnior AC, Rocha EP, } \\
\text { Bonfante EA, Almeida EO, } \\
\text { Anchieta RB, Martini AP, } \\
\text { Assunção WG, Silva NR, Coelho } \\
\text { PG. }\end{array}$ & $\begin{array}{l}\text { Biomechanical evaluation of internal and } \\
\text { external hexagon platform switched implant- } \\
\text { abutment connections: An in vitro laboratory } \\
\text { and three-dimensional finite element analysis. }\end{array}$ & $\begin{array}{l}\text { Dent Mater 2012;28:218- } \\
228 .\end{array}$ & $\begin{array}{l}\text { Abutment with } \\
\text { reconstruction tested }\end{array}$ \\
\hline $\begin{array}{l}\text { Oderich E, Boff LL, Cardoso AC, } \\
\text { Magne P. }\end{array}$ & $\begin{array}{c}\text { Fatigue resistance and failure mode } \\
\text { adhesively restored custom implant zirconia } \\
\text { abutments }\end{array}$ & $\begin{array}{l}\text { Clin Oral Implants Res } \\
\text { 2012;23:1360-1368. }\end{array}$ & $\begin{array}{l}\text { Abutment with } \\
\text { reconstruction tested }\end{array}$ \\
\hline $\begin{array}{l}\text { Butignon LE, Basilio Mde A, } \\
\text { Pereira Rde P, Arioli Filho JN. }\end{array}$ & $\begin{array}{c}\text { Influence of three types of abutmets on } \\
\text { preload values before and after cyclic loading } \\
\text { with structural analysis by scanning electron } \\
\text { microscopy }\end{array}$ & $\begin{array}{l}\text { Int J Oral Maxillofac } \\
\text { Implants } \\
\text { 2013;28:e161-70. }\end{array}$ & $\frac{\text { No fracture strength test }}{\text { after cyclic loading }}$ \\
\hline $\begin{array}{l}\text { Freitas-Júnior AC, Almeida EO, } \\
\text { Bonfante EA, Silva NR, Coelho } \\
\text { PG. }\end{array}$ & $\begin{array}{c}\text { Reliability and failure modes of internal conical } \\
\text { dental implant connections }\end{array}$ & $\begin{array}{l}\text { Clin Oral Implants Res } \\
\text { 2013;24:197-202. }\end{array}$ & $\begin{array}{l}\text { Abutment with } \\
\text { reconstruction tested }\end{array}$ \\
\hline $\begin{array}{l}\text { Magne P, Silva M, Oderich E, } \\
\text { Boff LL, Enciso R. }\end{array}$ & $\begin{array}{l}\text { Damping behavior of implant-supported } \\
\text { restorations }\end{array}$ & $\begin{array}{l}\text { Clin Oral Implants Res } \\
\text { 2013;24:143-148. }\end{array}$ & $\frac{\text { No fracture strength test }}{\text { after cyclic loading }}$ \\
\hline $\begin{array}{c}\text { Protopapadaki M, Monaco EA Jr, } \\
\text { Kim HI, Davis EL. }\end{array}$ & $\begin{array}{l}\text { Comparison of fracture resistance of } \\
\text { pressable metal ceramic custom implant } \\
\text { abutment with a commercially fabricated } \\
\text { CAD/CAM zirconia implant abutment }\end{array}$ & $\begin{array}{l}\text { J Prosthet Dent } \\
\text { 2013;110:389-396. }\end{array}$ & $\frac{\text { Abutment with }}{\text { reconstruction tested }}$ \\
\hline
\end{tabular}




\begin{tabular}{c|c|c|c|}
\hline $\begin{array}{c}\text { Mühlemann S, Truninger TC, } \\
\text { Stawarczyk B, Hämmerle CH, } \\
\text { Sailer I. }\end{array}$ & $\begin{array}{c}\text { Bending moments of zirconia and titanium } \\
\text { implant abutments supporting all-ceramic } \\
\text { crowns after aging }\end{array}$ & $\begin{array}{c}\text { Clin Oral Implants Res } \\
2014 ; 25: 74-81 .\end{array}$ & $\begin{array}{c}\text { Abutment with } \\
\text { reconstruction tested }\end{array}$ \\
$\begin{array}{c}\text { Nothdurft FP, Neumann K, } \\
\text { Knauber AW. }\end{array}$ & $\begin{array}{c}\text { Fracture behavior of zirconia implant } \\
\text { abutments is influenced by superstructure } \\
\text { geometry }\end{array}$ & $\begin{array}{c}\text { Clin Oral Investig } \\
2014 ; 18: 1467-1472 .\end{array}$ & $\underline{\text { reconstruction tested }}$ \\
\hline $\begin{array}{c}\text { Rosentritt M, Hagemann A, } \\
\text { Hahnel S, Behr M, Preis V. }\end{array}$ & $\begin{array}{c}\text { In vitro performance of zirconia and titanium } \\
\text { implant/abutment systems for anterior } \\
\text { application }\end{array}$ & J Dent \\
\hline
\end{tabular}

able 4. Articles excluded after full-text reading that did not met the inclusion criteria. 